\title{
The triatominae species of French Guiana (Heteroptera: Reduviidae)
}

\author{
Jean-Michel Bérenger ${ }^{1,2}{ }^{+}$, Dominique Pluot-Sigwalt ${ }^{1}$, Frédéric Pagès ${ }^{2}$, \\ Denis Blanchet ${ }^{3}$, Christine Aznar ${ }^{3}$
}

\begin{abstract}
${ }^{1}$ Muséum National d'Histoire Naturelle, Département Systématique \& Evolution (Entomologie), 45 rue Buffon, 75005 Paris, France ${ }^{2}$ Institut de Médecine Tropicale du Service de Santé des Armées, Allée du Médecin Colonel Jamot, Marseille, France ${ }^{3}$ Laboratoire Hospitalier

Universitaire de Parasitologie et Mycologie, UFR de Médecine, Université des Antilles et de la Guyane, Cayenne, Guyane Française
\end{abstract}

An annotated list of the triatomine species present in French Guiana is given. It is based on field collections carried out between 1993-2008, museum collections and a literature review. Fourteen species, representing four tribes and six genera, are now known in this country and are illustrated (habitus). Three species are recorded from French Guiana for the first time: Cavernicola pilosa, Microtriatoma trinidadensis and Rhodnius paraensis. The two most common and widely distributed species are Panstrongylus geniculatus and Rhodnius pictipes. The presence of two species (Panstrongylus megistus and Triatoma maculata) could be fortuitous and requires confirmation. Also, the presence of Rhodnius prolixus is doubtful; while it was previously recorded in French Guiana, it was probably mistaken for R. robustus. A key for French Guiana's triatomine species is provided.

Key words: Heteroptera - Reduviidae - Triatominae - French Guiana

Within the large family of Reduviidae, comprising more than 6,000 known species (Maldonado Capriles 1990), one subfamily, the hematophagous Triatominae is of great importance for human health because many of them are vectors of the Trypanosoma cruzi parasite responsible for Chagas disease. This fact explains why more than $80 \%$ of scientific publications about reduvids concern only triatomines, which comprise no more than 140 valid species (Costa \& Lorenzo 2009, Schofield \& Galvão 2009). The group is mainly diversified in the New World and roughly 20 species have been recorded in the Amazonian Region (Lent \& Wygodzinsky 1979, Barret \& Arias 1985, Serra et al. 1987, Lent et al. 1995, Coura et al. 2002, Costa \& Lorenzo 2009).

However, relatively few investigations have been conducted regarding the triatomine fauna of French Guiana. The first lists given by Floch and Abonnenc $(1941,1943)$ reported five species in 1941 and six in 1943. In their revision, Lent and Wygodzinsky (1979) mentioned six species in French Guiana, chiefly based on a Floch’s publication (1947). In 1983, Chippaux et al. listed eight species belonging to four genera, but this data was omitted by Ryckman (1986), who noted only six species from French Guiana. In 2003, Galvão et al. mentioned seven species. Finally, considering a larger area called "humid Guyana" (comprising French Guiana, Guyana and Surinam), AbadFranch and Monteiro (2007) compiled a list of 14 species, including four species considered as "possibly present".

Financial support: CPER/DocUP 2000-2006 (2364, Convention 421), Bioécologie et taux d'infestation des triatomes en Guyane, agents vecteurs de la maladie de Chagas

+Corresponding author: jmberenger@free.fr

Received 17 June 2009

Accepted 7 October 2009
Thus, during the last few decades, no precise investigation has been conducted of the French Guiana's triatomine fauna [apart from the studies of Chippaux (1984) and Chippaux et al. (1985), which provide interesting data] and the group remains to be thoroughly investigated.

After a first assessment on this subject (Aznar et al. 2000), we summarise here the results of many searches, mainly from field sampling, carried out between 19932008. Concerning the medical aspect of these species, studies devoted to their infection by T. cruzi in French Guiana have been led by Aznar (since 1997) using molecular biology. Relevant recent data from these investigations will be published separately (D Blanchet et al., unpublished observations).

\section{MATERIALS AND METHODS}

From 1993-2008, we have undertaken regular collections of reduvid specimens in French Guiana, mainly during 10 or so field trips to the country and also through permanent collaborations with several resident colleagues and friends. Each collecting stay lasted from 2-4 weeks, usually during the dry season, except for two stays made during the rainy season. The aim for one of us (JMB) was to compile a faunistic list of the reduvid fauna in this country, a plan that is still in progress. The triatomine fauna has been studied specifically. Several museum collections, in particular those of the Muséum National d'Histoire Naturelle (MNHN, Paris) and the Institut Pasteur (Paris), were also examined. In addition, two recent prospecting trips $(2007,2008)$ made around three military bases provided complementary data; these trips were particularly devoted to the triatomine and to the study of Chagas disease in French Guiana.

Insects were mainly caught using a light source; roughly 100 light trap sessions were conducted. During the two last prospecting trips, 15 light trap sessions were carried out from $7 \mathrm{pm}$ to midnight and for each triatomine specimen, the time of the catch was noted. The light 
trap was composed of a white sheet vertically stretched and lit on each side by two 125-W ballast bulbs, with or without a calling light and a white sheet on the ground. On some occasions, a vertical sheet was extended on each side, using a $5 \mathrm{~m}$ longer sheet to create a brightness gradient. Bugs were also actively searched for at night by sight, mainly around public or residential lighting. In total, several hundred triatomine specimens were captured and examined between 1993-2008. Identified triatomine specimens were deposited in the first author's collection (JMB), in the MNHN collection and in the collection of the Faculty of Medicine in Cayenne.

The prospecting sites (Fig. 16) included (i) a large area along the coast (Kaw, Patawa, Regina, Cacao, Cayenne and the area around, Sinnamary, Kourou, Iracoubo, Mana), (ii) various places along several rivers (the Maroni River: St-Laurent, St-Jean, Grand-Santi, Maripasoula and the Oyapock River: St-Georges, Camopi), (iii) the vicinity of Saül, located in the centre of French Guiana and in some places not easily accessible (Mitaraka Mountains) with the assistance of entomological associations (Alabama, Guyanentomo, Société Entomologique Antilles-Guyane) and (iv) around military bases (the centre for entertainment in the tropical forest, CEFE Régina, GSMA of St-Jean du Maroni and the Spatial Base of Kourou).

Sampling was performed in different environments: domestic and peridomestic, urban, rural and sylvan. Over the last 30 years, French Guiana's population has increased from 70,000 to 200,000 people (illegal workers not included) [Institut National de la Statistique et des Etudes Economique - INSEE 2009 (www.insee.fr/ guyane)]. This large increase induced the quick development of human dwellings, residential areas and unplanned urbanisation near forests or incorporating forest islands. This particular environment is referred to below as the "urban forest island."

The climate of French Guiana is equatorial, warm and humid, with little change in temperature during the year. The average annual temperature is $27^{\circ} \mathrm{C}$ and the annual precipitation measures more than $2.500 \mathrm{~mm}$.

\section{RESULTS}

Attracting only adult specimens, light traps cannot divulge any information on the biology of the collected triatomine species. However, this method does give information on the period of activity of the species. Our experience during several years shows that after midnight, the total catch of triatomine specimens is scarce (this is the same for all reduvids species). A maximum of individuals was collected between 9-11 pm.

During our investigation, 14 triatomine species were recorded in French Guiana (Table). Among these, the presence of 11 species has been confirmed; three other species require confirmation, not having been collected by us. Two additional species, at first considered as possibly present, were subsequently dismissed.

Confirmed species - From the 11 species collected by us, six were historically known to be present in French Guiana (i.e., prior to our 1993 investigation):
TABLE

List of the triatomine species recorded from French Guiana - literature data and present investigations (1993-2008)

\begin{tabular}{|c|c|}
\hline Literature data & Present study 1993-2008 \\
\hline- & Microtriatoma trinidadensis \\
\hline- & Cavernicola pilosa \\
\hline- & Rhodnius amazonicus \\
\hline- & Rhodnius paraensis \\
\hline Rhodnius pictipes & Rhodnius pictipes \\
\hline Rhodnius prolixus ${ }^{a}$ & - \\
\hline Rhodnius robustus & Rhodnius robustus \\
\hline Eratyrus mucronatus & Eratyrus mucronatus \\
\hline Panstrongylus geniculatus & Panstrongylus geniculatus \\
\hline Panstrongylus lignarius & Panstrongylus lignarius \\
\hline- & Panstrongulus mitarakaensis \\
\hline- & Panstrongylus megistus ${ }^{c}$ \\
\hline Panstrongylus rufotuberculatus & Panstrongylus rufotuberculatus \\
\hline Triatoma maculata ${ }^{b}$ & - \\
\hline Triatoma rubrofasciata & Triatoma rubrofasciata ${ }^{c}$ \\
\hline
\end{tabular}
$a$ : probable misidentification; $b$ : need confirmation; $c$ : from museum specimens.

Panstrongylus geniculatus (Latreille), Panstrongylus rufotuberculatus (Champion), Panstrongylus lignarius (Walker), Rhodnius pictipes Stål, Rhodnius robustus Larrousse and Eratyrus mucronatus Stål. Five species were not previously known in this country (see catch localities in Fig. 16): Cavernicola pilosa Barber, Microtriatoma trinidadensis (Lent) and Rhodnius paraensis Sherlock et al. were not recorded previously in French Guiana. Rhodnius amazonicus Almeida et al. was recently restored as a valid species (Bérenger \& Pluot-Sigwalt 2002). Panstrongylus mitarakaensis Bérenger and Blanchet is a newly described species (Bérenger \& Blanchet 2007).

Of these 11 species, only two appear to be very common in French Guiana, $P$. geniculatus and $R$. pictipes, which are widely distributed in the Amazonian Region.

Species requiring confirmation - The presence of four triatomine species not collected by us during our investigation requires confirmation. These species seem very rare, accidental, or possibly now missing in the country. Triatoma maculata (Erichson) and Triatoma rubrofasciata (De Geer) are cited in the literature from French Guiana. The presence of the former is probable because this species occurs in Surinam; we found four specimens of the latter in museum collections, but the species could have disappeared from French Guiana. Panstrongylus megistus (Burmeister) has been found, only as poorly labelled specimens, preserved in museum collections.

Potential species - It is very likely that species other than those listed in the present paper are present in French Guiana, particularly six species described in Brazil [Pará (PA), principally]: Cavernicola lenti Barret and 
Arias, Rhodnius brethesi Matta, Belminus herreri Lent and Wygodzinsky, Belminus laportei Lent et al., Psammolestes tertius Lent and Jurberg and Alberprosenia malheiroi Serra et al.

Excluded species - The presence of Rhodnius prolixus is likely a mistake. Although cited from French Guiana by Floch and Abonnenc (1941), Lent and Wygodzinsky (1979), Chippaux et al. (1985), Maldonado Capriles (1990), Carcavallo et al. (1999) and Galvão et al. (2003), we have excluded $R$. prolixus from our list. Several facts lead us to think that the species does not occur in French Guiana.

Misidentification is strongly suspected. $R$. prolixus and $R$. robustus are extremely similar and difficult to separate morphologically (Miles et al. 1981, Harry 1993a, b). R. prolixus is cited from French Guiana by Floch and Abonnenc (1941) based on a single female collected on the Comté River. In order to identify the specimen, Floch used the works of Larrousse (1927) and Neiva and Lent (1941), which did not allow for a rigorous distinction between $R$. prolixus and $R$. robustus. Later, Chippaux et al. (1985) again listed $R$. prolixus in French Guiana, despite Miles' opinion (Miles et al. 1983); Miles had doubts as to the presence of the species in French Guiana and he assigned the specimens identified by Chippaux to $R$. robustus [Miles in litt. cited by Chippaux et al. (1985)]. Unfortunately, we could not find and examine the specimens in question.

Other data seem to exclude $R$. prolixus from French Guiana. Recent studies in molecular biology and phylogeography (Monteiro et al. 2003, Pavan \& Monteiro 2007) show that the Guyana Shield is located out of the distribution area of $R$. prolixus. According to these studies, the species is present north of the Amazonian Basin, in Central America and in the non-Amazonian zone of Colombia and Venezuela. Records of R. prolixus in Brazil may be due to confusion with $R$. robustus and Rhodnius neglectus Lent, 1954 (Gurgel-Gonçalves et al. 2008).

The case of Triatoma brasiliensis Neiva, 1911 is also in dispute. We have found only a single male specimen in the MNHN collection (Fig. 14), simply labelled "Guyane française”. Considering that the geographical distribution of T. brasiliensis is restricted to the semiarid areas of North-eastern Brazil (Lent \& Wygodzinsky 1979, Costa et al. 2003) we consider the species as not present in French Guiana until further information is available.

\section{Annotated list of French Guiana's triatomines}

\section{Bolboderini Usinger, 1944

$$
\text { M. trinidadensis (Lent, 1951) }
$$

(Fig. 7)

One specimen of this arboreal species was captured in the primary forest area. It was found on the extension of the sheet of the light trap (brightness gradient).

Distribution - Montagne des Singes (near Kourou).

Cavernicolini Usinger, 1944

$$
\text { C. pilosa Barber, } 1937
$$

Three specimens have been collected, each time in forested areas. The bug does not stay on the sheet of the light trap; it escapes very quickly requires vigilance to catch it. This fleetness could explain why the species is so rare in the museum collections.

Distribution - Piste changement (near Kourou), montagne de Kaw (PK 37).

Rhodniini Pinto, 1926

R. amazonicus Almeida, Santos \& Sposina, 1973

(Fig. 11)

We have collected and studied five specimens, which allowed the rehabilitation of $R$. amazonicus as a valid species (Bérenger \& Pluot-Sigwalt 2002). It is a sylvatic species, captured by light and apparently very rare.

Distribution - Saül, degrad Kwata (near Cacao), Bélizon, Tibourou.

\section{R. paraensis Sherlock, Guitton \& Miles, 1977}

(Fig. 9)

Three specimens were collected by light trap, each time on the sheet on the ground.

Distribution - Degrad Kwata (near Cacao), CEFE (Regina), Bélizon.

$$
\text { R. pictipes Stål, } 1872
$$

(Fig. 10)

It is the most common triatomine species in French Guiana, after $P$. geniculatus. It is often captured by light in forest areas, but we also found it near human dwellings in forested areas. More than 50 specimens were collected.

\section{R. robustus Larrousse, 1927}

(Fig. 12)

This species is usually caught in urban areas and urban forest island areas (Cayenne, Montjoly, Matoury, Macouria (near Tonate); some specimens were also collected around Grand-Santi village. We found it more scarcely in forested areas (Kaw mountain). About 20 specimens were collected.

Triatomini Jeannel, 1919

$$
\text { E. mucronatus Stål, } 1859
$$

(Fig. 5)

This species is common in forest areas, present near human dwellings in forest areas and rarely present in urban areas. About 40 specimens were collected.

Distribution - Kaw Mountain, Kaw village, PetitSaut dam, Saül, Grand-Santi, Kourou, Sinnamary, Nancibo, Cacao, Roura. Villiers (1971) found it on the Oyapock River (Saut Maripa, Alicoto).

$$
\text { P. geniculatus (Latreille, 1811) }
$$

(Fig. 1)

Clearly the most common and the most widely distributed French Guiana's triatomine species, it was found in all parts of the country and in all environments (urban areas, 
urban forest island areas and sylvan areas). It was collected mainly by light trap and according to Chippaux et al. (1983) and our own experience, it represents $80 \%$ of the triatomine species collected in sylvan areas and near human dwellings. We have collected more than 100 specimens.

\section{P. lignarius (Walker, 1873)}

(Fig. 2)

This species is uncommon; about 20 specimens were collected by light in sylvan areas and near urban forest island areas.

Distribution - Cayenne (Mt Saint-Martin), Kaw, Belizon, Saül, Kourou, Cacao, Bélizon, Petit Saut dam.

\section{P. megistus (Burmeister, 1835)}

(Fig. 13)

We never collected $P$. megistus. We found only one male specimen labelled French Guiana (without further indication) in the MNHN collection. We consider that the species could be present in French Guiana, being widely distributed in the Northeastern Brazil, in particular in PA (Lent \& Wygodzinsky 1979, Galvão et al. 2003). Chippaux (1984) hypothesised that $P$. megistus might have arrived in PA using merchandise transport and he thought that the species may have arrived in French Guiana in the same way.
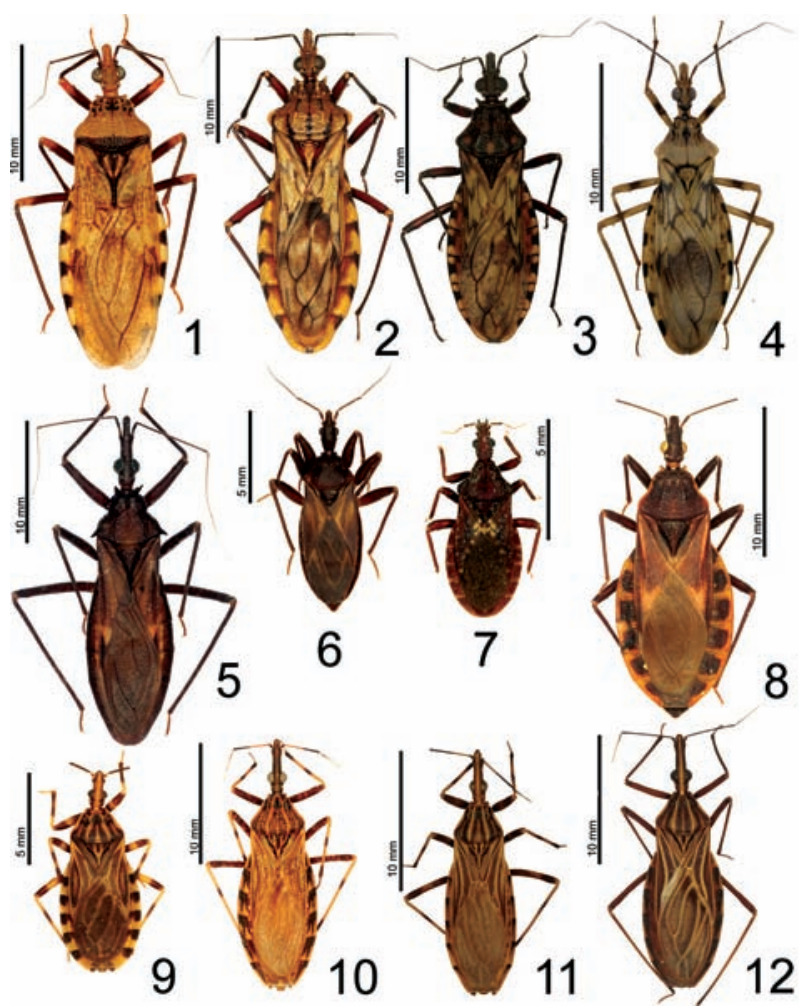

Fig 1-12: triatomine habitus. 1: Panstrongylus geniculatus; 2: Panstrongylus lignarius; 3: Panstrongylus rufotuberculatus; 4: Panstrongylus mitarakaensis; 5: Eratyrus mucronatus; 6: Cavernicola pilosa; 7: Microtriatoma trinidadensis; 8: Triatoma rubrofasciata; 9: Rhodnius paraensis; 10: Rhodnius pictipes; 11: Rhodnius amazonicus; 12: Rhodnius robustus (photos: JMB).

\section{P. mitarakaensis Bérenger \& Blanchet, 2007} (Fig. 4)

A single specimen was collected in the Mitaraka Mountains, South-West of French Guiana on the Brazil frontier, an arid zone with granite outcrops (inselberg).

\section{P. rufotuberculatus (Champion, 1899)}

(Fig. 3)

This uncommon species was collected by light in forest areas. About 20 specimens were collected.

Distribution - Awala-Yalimapo (near Mana), Kaw, Belizon, Saül, Cacao, Kourou.

\section{T. maculata (Erichson, 1848)}

(Fig. 15)

T. maculata was recorded in French Guiana and borderlands by Carcavallo et al. (1999), Galvão et al. (2003) and Jurberg and Galvão (2006). However, we never collected it and cannot confirm its presence. If present, it may be rare.

\section{T. rubrofasciata (De Geer, 1773)}

(Fig. 8)

We never collected any specimens of T. rubrofasciata. The species seems to have disappeared. A possible reason could be a successful fight against rodents that has eliminated both the bugs and its hosts. If $T$. rubrofasciata is still present in Cayenne, it is certainly not abundant.

After the Second World War, the species seemed to be relatively common in French Guiana. This can be deduced from the great number of specimens collected in 1945 (Floch \& Abonnenc 1941, Floch \& Lajudie 1945, Floch 1947) in Cayenne and around human dwellings. Although Chippaux et al. (1985) did not collect any specimens of this species, they recorded $T$. rubrofasciata with the notation - not very abundant -.

In the MNHN collection, we found a female specimen labelled "coll. Bar Oberthur, 1899, Guyane Française" and three more recent specimens labelled "1975, trouvé dans habitations à Cayenne".
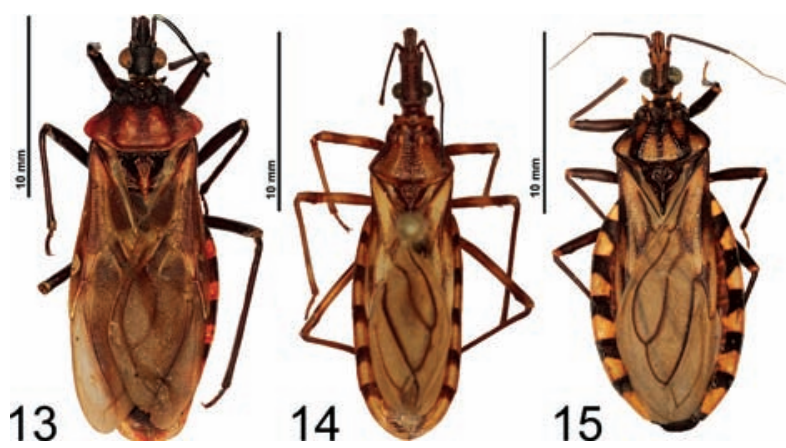

Fig 13-15: triatomine habitus. 13: Panstrongylus megistus; 14: Triatoma brasiliensis (Muséum National d'Histoire Naturelle collection); 15: Triatoma maculata (Venezuela, coll. JMB). 


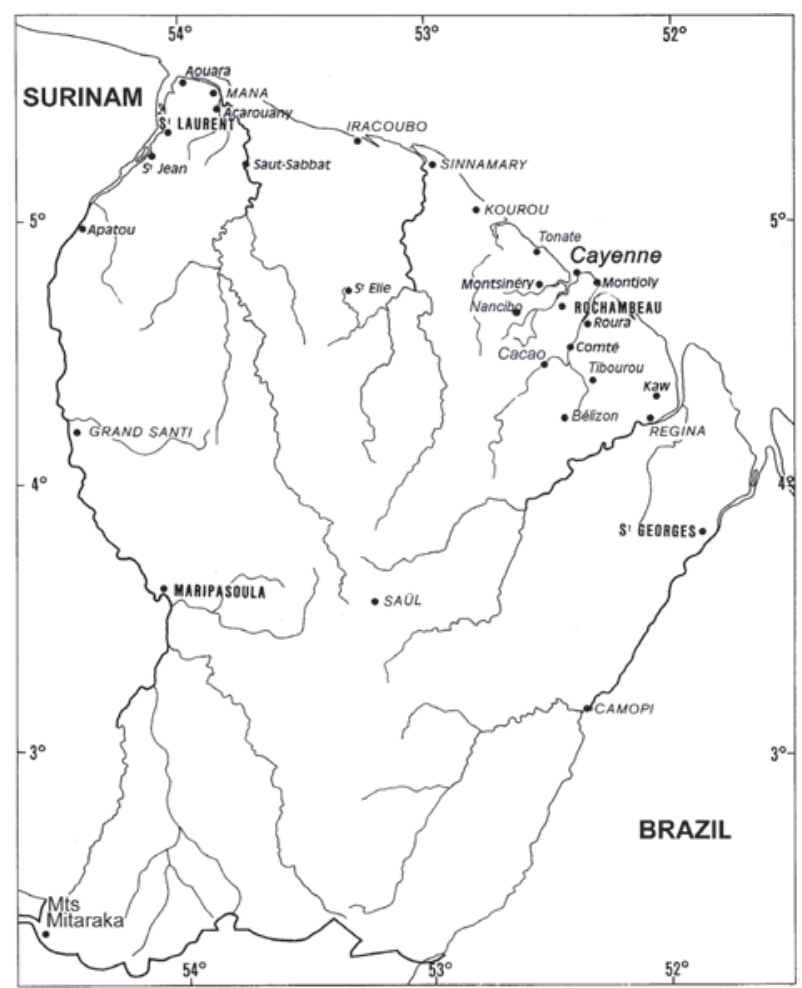

Fig. 16: main collecting point locations in French Guiana between 1993-2008.

\section{Key to the triatomine species from French Guiana}

1. Genae conspicuously surpassing apex of clypeus . ..M. trinidadensis

- Genae not surpassing apex of clypeus ... 2

2. Head ovoid and convex in lateral view ....C. pilosa - Head never ovoid or convex .. 3

3. Antennae inserted near the apex of the head. Postocular region with callus and setigerous tubercles ...... 4

- Antennae inserted far from the apex of the head. Postocular region without lateral callus .... ... 7

4. Meso and metatibiae at least with a black median annulus.

- Tibiae without black annulus.

$R$ robustus

5. Length < $12 \mathrm{~mm}$; protibiae without black annuli ..

- Length > 15 mm; all tibiae annulate . $R$. paraensis

6. Brown colour of femora and corium uniform ........ R. amazonicus

- Femora and corium brown with irregular yellowish spots R. pictipes

7. Humeral angle of pronotum and process of scutellum spinose... E. mucronatus

- Humeral angle of pronotum and process of scutellum without spine .

8. Antennae insertion close to the eyes 9
- Antennae insertion situated about the middle of preocular region of head 13

9. Femora light with a black median annulus .

- Femora without black annulus. P. mitarakaensis

10. Anterior lobe of pronotum with lateral and discal tubercles reduced or erased; posterior margin of pronotum with a black strip... P. geniculatus

- Anterior lobe of pronotum with lateral and discal tubercles prominent; posterior margin of pronotum without black strip

11. Posterior lobe of pronotum yellowish with seven black longitudinal strips .... $P$. lignarius

- Posterior lobe of pronotum blackish or reddish with three black longitudinal strips 12

12. Pronotum blackish with three yellowish spots on posterior margin .... P. rufotuberculatus

- Pronotum black with four reddish spots more or less spread. P. megistus

13. Membrane of hemelytra blackish; vein of membrane inconspicuous T. rubrofasciata

- Membrane of hemelytra light brown; vein of membrane black and conspicuous T. maculata

\section{ACKNOWLEDGEMENTS}

To our colleagues and friends who kindly collected for us triatomine specimens during their field collections: B Hermier, J Cerda, O Morvan, I Curtet, M Thouvenot, JJ Briswalter, JC Streito (LNPV Montpellier), R Rougerie, HP Aberlenc (CIRAD), R Garrouste (MNHN), P Cerdan (Labo Hydreco), P Causse, Y Hauray, D et L Rignon, H de Toulgoët, G Tavakilian (IRD), JP Vesco, Alabama Association, JP Champenois (Guyanentomo), PH Dalens (SEAG), to Dr Delesquen, chief of the French Army Health Service in French Guiana, to Sandy Jones, for her comments, and to the anonymous referees, for the relevant suggestions.

\section{REFERENCES}

Abad-Franch F, Monteiro FA 2007. Biogeography and evolution of Amazonian triatomines (Heteroptera: Reduviidae): implications for Chagas disease surveillance in humid forest ecoregions. Mem Inst Oswaldo Cruz 102 (Suppl. I): 57-69.

Aznar C, Bérenger JM, Garrouste R, Hontebeyrie M, Carme B, Pluot-Sigwalt D 2000. Triatomines species (Hemiptera: Reduviidae: Triatominae) and Trypanosoma cruzi in French Guiana. Congresso Internacional de Entomologia, Foz do Iguaçu, Brasil 19-26 vol. agosto de 2000, II: p. 763.

Barrett TV, Arias JR 1985. A new Triatominae host of Trypanosoma from the central Amazon of Brasil, Cavernicola lenti n. sp. Mem Inst Oswaldo Cruz 80: 91-96.

Bérenger JM, Blanchet D 2007. A new species of the genus Panstrongylus from French Guiana (Heteroptera: Reduviidae: Triatominae). Mem Inst Oswaldo Cruz 102: 733-736.

Bérenger JM, Pluot-Sigwalt D 2002. Rhodnius amazonicus Almeida, Santos \& Sposina, 1973, bona species, close to R. pictipes Stål, 1872 (Heteroptera: Reduviidae: Triatominae). Mem Inst Oswaldo Cruz 97: 73-77.

Carcavallo RU, Curto de Casas SI, Sherlock IA, Galindez Giron GI, Jurberg J, Galvão C, Mena Segura CA, Noireau F 1999. Geograph- 
ical distribution and alti-latitudinal dispersion. In RU Carcavallo, I Galindez Giron, J Jurberg, H Lent, Atlas of Chagas' disease vectors in the Americas, Fiocruz, Rio de Janeiro, p. 747-792.

Chippaux JP 1984. Etude systématique et écologique des Triatomes de Guyane française. D.E.A. d’Entomologie, Université Paris VI, Paris, 48 pp.

Chippaux JP, Dedet JP, Geoffroy G, Tavakilian G, Pajot FX 1983. La maladie de Chagas en Guyane Française. La Nature et l'Homme en Guyane, ORSTOM et Institut Pasteur, Cayenne, 32 pp.

Chippaux JP, Pajot FX, Geoffroy B, Tavakilian G 1985. Etude préliminaire sur l'écologie et la systématique des Triatomes (Hemiptera: Reduviidae) de Guyane Française. Cah ORSTOM, Entomol Med Parasitol 23: 75-85.

Costa J, Almeida CE, Dotson EM, Lins A, Vinhaes M, Silveira AC, Beard CB 2003. The epidemiological importance of Triatoma brasiliensis as a Chagas disease vector in Brazil: a revision of domiciliary captures during 1993-1999. Mem Inst Oswaldo Cruz 98: 443-449.

Costa J, Lorenzo M 2009. Biology, diversity and strategies for the monitoring and control of triatomines - Chagas disease vectors. Mem Inst Oswaldo Cruz 104 (Suppl. I): 46-51.

Coura JR, Junqueira ACV, Fernandes O, Valente SAS, Miles MA 2002. Emerging Chagas disease in Amazonian Brazil. Trends Parasitol 18: 171-176.

Floch H 1947. La maladie de Chagas en Guyane française. Publ Inst Pasteur Guyane Territ Inini 164: 1-5.

Floch H, Abonnenc E 1941. Recherche de la trypanosomiase humaine américaine en Guyane française. Les Triatomidés vecteurs. Publ Inst Pasteur Guyane Territ Inini 23: 1-6.

Floch H, Abonnenc E 1943. Triatomidés et maladie de Chagas. Présence de E. mucronatus en Guyane française et infection naturelle de $R$. pictipes par S. cruzi. Publ Inst Pasteur Guyane Territ Inini 70: 1-4.

Floch H, de Lajudie P 1945. Recherches sur la trypanosomiase humaine Américaine en Guyane française. Rhodnius prolixus et Rhodnius pictipes vecteurs naturels de choix de S. cruzi. Publ Inst Pasteur Guyane Territ Inini 117: 1-5.

Galvão C, Carcavallo R, Rocha DS, Jurberg J 2003. A checklist of the current valid species of the subfamily Triatominae Jeannel, 1919 (Hemiptera: Reduviidae) and their geographical distribution, with nomenclatural and taxonomic notes. Zootaxa 202: 1-36.

Gurgel-Gonçalves R, Abad-Franch F, Ferreira JBC, Santana DB, Cuba Cuba CA 2008. Is Rhodnius prolixus (Triatominae) invading houses in Central Brazil? Acta Trop 107: 90-98.

Harry M 1993a. Use of the median process of the pygophore in the identification of Rhodnius nasutus, $R$. neglectus, $R$. prolixus and $R$. robustus (Hemiptera: Reduviidae). Ann Trop Med Parasitol 87: 277-282.
Harry M 1993b. Isozymic data question the specific status of some blood-sucking bugs of the genus Rhodnius, vectors of Chagas disease. Trans Roy Soc Trop Med Hyg 87: 492.

Jurberg J, Galvão C 2006. Biology, ecology and systematics of Triatominae (Heteroptera: Reduviidae) vectors of Chagas disease and implications for human health. Denisia 19: 1096-1116.

Larrousse F 1927. Etude biologique et systématique du genre Rhodnius Stal (Hémiptères, Reduviidae). Ann Parasitol Hum Comp 5: 63-88.

Lent H, Jurberg J, Carcavallo RU 1995. Belminus laportei sp. n. da Região Amazônica. Mem Inst Oswaldo Cruz 90: 33-39.

Lent H, Wygodzinsky P 1979. Revision of the Triatominae (Hemiptera: Reduviidae) and their significance as vectors of Chagas' disease. Bull Am Mus Nat Hist 163: 123-520.

Maldonado Capriles J 1990. Systematic catalogue of the Reduviidae of the world (Insecta: Heteroptera), Carib J Sci, Special Edition, Mayagüez, 694 pp.

Miles MA, Arias JR, Souza AA 1983. Chagas disease in the Amazon Basin. V. Periurban palms as habitat of Rhodnius robustus and Rhodnius pictipes - Triatominae vectors of Chagas disease. Mem Inst Oswaldo Cruz 78: 391-398.

Miles MA, Souza AA, Povoa M 1981. Chagas' disease in the Amazon Basin. III. Ecotopes of ten triatomine bug species (Hemiptera: Reduviidae) from the vicinity of Belem, Para state, Brazil. J Med Entomol 18: 255-278.

Monteiro FA, Barrett TV, Fitzpatrick S, Cordon-Rosales C, Feliciangeli D, Beard CB 2003. Molecular phylogeography of the Amazonian Chagas disease vectors Rhodnius prolixus and $R$. robustus. Mol Ecol 12: 997-1006.

Neiva A, Lent H 1941. Sinopse dos triatomideos. Rev Entomol (Rio J) 12: 61-92.

Pavan MG, Monteiro FA 2007. A multiplex PCR assay that separates Rhodnius prolixus from members of the Rhodnius robustus cryptic species complex (Hemiptera: Reduviidae). Trop Med Int Health 12: 751-758.

Ryckman RE 1986. The triatominae of South America. A check list with synonymy. Bull Soc Vect Ecol 11: 199-208.

Schofield CJ, Galvão C 2009. Classification, evolution and species groups within the Triatominae. Acta Trop 110: 88-100.

Serra RG, Atzingen NCB, Serra OP 1987. Nueva especie del genero Alberprosenia Martinez y Carcavallo, 1977, del estado de Pará, Brasil. Chagas 4: 475.

Villiers A 1971. Reduviidae (Heteroptera) récoltés en Guyane française par la mission du Muséum National d'Histoire Naturelle. Ann Soc Entomol Fr (N.S.) 7: 679-684. 